\title{
Ambiwalentny obraz faweli Santa Marta na tle przemian pacyfikacyjnych
}

PRZEGLĄD KRYTYCZNY 2021 / 3(1): 51-64 ISSN: $2657-8964$ DOI: $10.14746 / \mathrm{pk} .2021 .3 .1 .3$

\section{Kamil Lipiński ${ }^{1}$ \\ ${ }^{1}$ Uniwersytet w Białymstoku, Instytut Studiów Kulturowych, Wydział Filologiczny, ul. Świerkowa 20b, 15-328 Białystok, ORCID: 0000-0001-5109-3698, Email: lipinski_kamil@yahoo.com}

Streszczenie: Celem niniejszego artykułu jest próba opisu przemian faweli Santa Marta w Rio de Janeiro, ambiwalentnego obrazu tej przestrzeni zrodzonego po jej pacyfikacji i widzianego przez pryzmat postindustrialnej analizy Edwarda Soi. W tym celu autor omawia potencjalne zagrożenia związane z separacją jej od innych części miasta, gatekeepingiem i inkryminacją. Ostatnie uwagi dotyczą zaś tego, jak restrukturyzacja faweli Santa Marta, pomimo swojej kryminalnej historii, artykułuje nowe rozwiązania poprzez wzbudzenie zainteresowania zwiedzających wraz z wielobarwnym kolorowaniem fasad domów mieszkalnych u stóp wzgórza w ramach projektu Oh Morro Jeroena Koolhaasa i Dre Urhahna.

Słowa kluczowe: Rio de Janeiro, Santa Marta, wzgórze, separacja, pacyfikacja, taras widokowy, gentryfikacja

\section{WPROWADZENIE}

$\mathrm{N}^{\mathrm{i}}$ ie ma współcześnie nic zdrożnego w stwierdzeniu, iż przeobrażenia miejskie bywają niekiedy kontrowersyjne. Problematyka podejmowana w niniejszym szkicu dotyczy próby opisu przemian wzgórza Santa Marta w Rio de Janeiro, omówienia podejmowania wysiłków w celu zerwania z jego niekorzystną reputacją poprzez wprowadzenie programu pacyfikacji i szeregu kreatywnych projektów, służących otwarciu tej dzielnicy dla szerszego grona odwiedzających. Zasadniczym przedmiotem rozważań będą wewnętrzne relacje i asymetria zachodząca pomiędzy podnóżem wzgórza a jej szczytem, określane mianem „post-pacyfikacji” tej dzielnicy, z uwagi na pozorne pozostawanie pod czujnym okiem władz (Luici de Oliveira 2014: 13). W ramach różnych koncepcji dotyczących czy to krytycznych studiów miejskich, czy poszczególnych studiów przypadku analizy ubogich dzielnic miejskich odmiennie bowiem ujmuje się relację między polityką miejską a badaniami nad kulturą. W związku z tym inaczej widzi 
się rolę przestrzenności w poznawaniu tej sfery zjawisk. Kultura pojmowana przez pryzmat samych prób rekreacji doświadczenia estetycznego pozbawiona jest tych cech i zależności, które ujawniły się dopiero w badaniach zorientowanych na analizę ich wernakularnej specyfiki i ekonomicznych podstaw. Spróbujmy najpierw ukazać, jak z tego punktu widzenia przedstawiają się relacje między „odgórnymi” zarządzeniami władz a „oddolnymi” inicjatywami związanymi z czerpaniem korzyści przez mieszkańców ubogich dzielnic. W dalszym ciągu można zastanowić się nad tym, czy podejmowana polityka miejska jest odpowiednia do tego, aby wskazane zadania realizować, a jeśli nie, to od jakich okoliczności zależy możliwość ich wprowadzenia w życie.

W szczególnej mierze poniższe ustalenia dotyczą próby podjęcia rewitalizacji faweli, poczynionej wraz z budową pomnika Michaela Jacksona na pamiątkę nagrania utworu They don't care about us i wielobarwnej fasady placu u stóp wzgórza, w ramach programu Oh Morro. Omawiając aspekty związane z uprawianiem turystyki, pragnę naświetlić wewnętrzne problemy w ramach faweli, oparte na napięciu między zakreśloną polityką rozwoju a ambiwalentnym podejściem miejscowych do odgórnie narzuconych przemian. Otóż „przedstawiciele geografii humanistycznej od Edwarda Soi dyskutującego z koncepcją heterotopii Foucaulta, spadkobierców Benjaminowskiego flâneura interpretują właściwą ponowoczesności humanizację środowiska naturalnego używając „miejsca” jako pojęcia-klucza otwierającego drzwi do nieograniczonej liczby procesów budujących nowe doświadczenie kulturowe (Rewers 1996: 49). Przedmiotem niniejszych rozważań będzie problematyka przestrzenna wzgórza, powiązana z dynamicznym opisem miejskiego krajobrazu. Jest to próba zarysowania, w jaki sposób:

wyobraźnia miejska (...) odnosi się do naszych mentalnych lub poznawczych mapowań miejskiej rzeczywistości i interpretacyjnych węzłów, przez które myślimy, doświadczamy, oceniamy i decydujemy się działać w miejscach, przestrzeniach i społecznościach, w których żyjemy. (...) Tym, co znaczenie zmieniło rekompozycje formy miejskiej i struktur społecznych oraz wiele innych sił kształtujących przemianę postmiejską jest nasza wyobraźnia miejska, rozmywając jej niegdyś o wiele wyraźniejsze granice i znaczenia. (Soja 2000: 324)

W obszarze najbardziej znaczących aspektów perspektywy teoretycznej należy wskazać przede wszystkim „zwiększenie się roli »polityki miejsca« wiązane ze wzrostem poziomu zaangażowania sąsiedzkiego w kwestie samorządu lokalnego" (Barker 2005: 420). Omawiana teoria, odwołująca się między innymi do koncepcji „ekologii strachu” Mike’a Davisa, odzwierciedla sposób, w jaki „krajobraz postmetropolitalny został wypełniony wieloma różnymi rodzajami chronionych i ufortyfikowanych przestrzeni, wysp" (Soja 2000: 299). Biorąc pod uwagę przeobrażenia miejskie, wiązane z wyłonieniem się odnowionych przestrzeni miejskich, chciejmy w tym miejscu nakreślić obraz stosunków zachodzących między polityką zewnętrzną a wewnętrzną, w obrębie których:

postmetropolis jest reprezentowane jako zbiór karceralnych miast, archipelagów »znormalizowanych ogrodzeń« i ufortyfikowanych przestrzeni, które zarówno dobrowolnie, jak i mimowolnie barykadują jednostki i społeczności na widocz- 
nych i mało widocznych wyspach miejskich. (Soja 2000: 299)

Obraz miasta naszkicowany w tej definicji koresponduje z opisem wizualnych przeobrażeń, dając do zrozumienia, że „tryb regulowania życia miejskiego i utrzymywania wewnętrznych przestrzeni w postmetropolis przesuwa się z twardych krawędzi egzekwowania i zamknięcia na łagodniejsze manipulowanie ideologią i przekształcanie wyobrażeń miejskich” (Soja 2000: 299). Proponowana analiza kieruje swoją uwagę na aspekty związane z wizualnością miejską, reorganizacją doświadczenia przestrzennego i przeobrażeniami polityki miejskiej. Perspektywa przestrzenna oparta na lekturze Edwarda Soi odnośnie sposobów rekompozycji doświadczenia miejskiego „nie musi oznaczać całkowitego przekształcenia obrazu miasta w zupełnie coś nowego”, lecz „zachowuje pewną ciągłość z przeszłością” (Barker 2005: 419). Mając na uwadze oscylację między tym, co teraźniejsze a tym, co historyczne, Soja uwypukla, w jaki sposób obszary są „przestrzennie przemieszane”, pozostając jednym z efektów restrukturyzacji i redystrybucji miejsc pracy i mieszkań (Barker 2005: 420). W tym ujęciu należy podkreślić, iż „zamieszkujący dane miejsce staje się w tej perspektywie działającym podmiotem, który nadaje znaczenie światu, a także jednostką oddziałującą na świat, którego ona lub on jest częścią"(Rewers 1996: 50-51). Aby uchwycić ten kontekst przemian analizy przestrzennej, Soja wprowadził koncepcję miasta-kalejdoskopu. W świetle tej koncepcji chciejmy spojrzeć wnikliwym okiem na przestrzeń „otoczonych murami osiedli mieszkaniowych, uzbrojonych strażników”, których celem jest „powstrzymanie zagrożeń związanych z przestępczością, przemocą, zróżnicowaniem etnicznym”, służących temu, aby uchwycić „wzrost poziomu zaangażowania sąsiedzkiego w kwestie samorządu lokalnego" (Barker 2005: 420). W zarysowanej perspektywie wspomniane przemiany służą „podniesieniu statusu miast na obrzeżach (edge cities), dzięki czemu możliwe staje się dowartościowanie statusu różnych przestrzeni” (Barker 2005: 421). Jeśli uwzględnimy ambicje skierowane w stronę przeformułowania przestrzeni miejskiej, wyłania się związek przestrzeni miejskiej z wyobraźnią artystyczną i sposobami reorganizacji doświadczenia przestrzennego i wizualnego. Przede wszystkim służy on po to, aby oddać sposób redefinicji tych obszarów, które wymagają szczególnej uwagi ze strony polityki zewnętrznej. Przedstawiony tu skrótowo sposób ujęcia przeobrażeń badań na przestrzenią miejską w nawiązaniu do krytycznych studiów kulturowych tym się charakteryzuje, że akcentuje to wszystko, co wiąże się z podwójną strategią reorganizacji doświadczenia miejskiego, celem dowartościowania nierówności społecznych i przybliżenia marginesów szerszemu gronu odbiorców przyciągniętych przez szereg rozmaitych atrakcji turystycznych. Koncepcję tę będę analizował na podstawie badań empirycznych w dialogu z teoretycznymi ustaleniami z zakresu urbanistyki i filozofii przestrzeni.

\section{HISTORYCZNE SPOJRZENIE NA PRZEOBRAŻENIA FAVELAS CARIOCAS}

Przystępując do wyodrębnienia z szerokiego spektrum przestrzeni miejskich w Rio de Janeiro , przyjrzyjmy się jednej z bardziej znaczących favelas cariocas, zlokalizowanej na wzgórzu Santa Marta w dzielnicy Botafogo na wzniesieniu Dona Marta. Powyższe studium będzie nas interesować jako case study procesów pacyfikacyjnych, skupionych 
na otwarciu biednych, inkryminowanych dzielnic na potencjalnych turystów, celem zmiany ich charakteru poprzez restrukturyzację miejsca i sposobów zarobkowania powiązanych z jednoczesnym ograniczeniem samego obszaru. Poszukując wspólnych cech różnie formułowanej „faweli”, zwłaszcza tych które mają konsekwencje badawcze, wyjdę od definicji Misha Glenny, wedle której w „faweli najbardziej wartościowa jest przestrzeń” (Glenny 2016: 35). Choć Santa Marta zajmuje stosunkowo niewielką powierzchnię, zamieszkuje ją około osiem tysięcy mieszkańców. Jej początki sięgają XX wieku, kiedy wzniesiono tam pierwszą kaplicę poświęconą Świętej Marcie, patronce zapracowanych. W swoim oryginalnym znaczeniu:

słowo »fawela«, które oznacza slums lub nieformalne domostwo, pojawiło się w Rio już pod koniec dziewiętnastego wieku. Pochodzi ono z Nordeste (Północno-Wschodniego regionu) Brazylii. W 1897 roku żołnierze wracający z prowincji Bahia, po stłumieniu powstania w Canudos rozbili obóz na jednym ze wzgórz w Rio i domagali się wypłacenia przez rząd zaległego żołdu. Wtedy jeszcze Rio było stolicą Brazylii. (...) zdemobilizowani mężczyźni wyprawili się do Rio i zatrzymali się na wzgórzu, na którym dziś znajduje się fawela o nazwie Providência. Ochrzcili je mianem wzgórza Fawela. Nazwa pochodzić miała, co jednak budzi wątpliwości, od nazwy wzgórza, gdzie mieściła się strategiczna baza mieszkańców Canudos. Niektórzy wywodzą termin od nazwy trującej i wytrzymałej rośliny porastającej zbocza góry Faweli. Wspomniani żołnierze, domagający się niewypłaconego żołdu byli równie nieustępliwi jak ta roślina na nieprzyjaznej glebie Nordeste. Gdy już zapuścili korzenie, rząd mimo starań nie dał rady wysiedlić ich z przybranego domu. (Glenny 2016: 44-45)

Sięgając genezy powstania faweli na owym wzgórzu, Jeanne Perlman sugerowała zaś, że „Santa Marta posiada historię jako niezależna organizacja społeczna sięgającą kilku pokoleń” (Perlman 2010: 168). Claude’a Lévi-Straussa, opisując ten fenomen, pisał, iż

być może urbanistyka znalazła obecnie rozwiązanie tego zagadnienia, lecz w roku 1935 można było ustalić stopień zajmowany w hierarchii społecznej za pomocą wysokościomierza: stopień ten był tym niższy, im mieszkanie było wyżej położone (...) Miasto zmienia się zarówno w miarę odległości, jak w miarę wysokości. Z chwilą, gdy zapuszczamy się w jedną z tych miejskich ścieżek, które zagłębiają się serpentynami pomiędzy wzgórza, mamy przed sobą wkrótce obraz przedmieścia. (Lévi-Strauss 1960: 32)

Powyższy opis poświęcony przestrzeni miejskiej z początków XX wieku zdaje się trafnie wskazywać na odrębność aglomeracji na wzgórzach od poniżej położonych części miasta. Stąd też wynikają różnorodne aspekty dysproporcji ekonomicznej i społecznej, a także zagrożeń, dla obcych wkraczających na teren tych dzielnic, płynących z faweli. Niewątpliwie jednak urbaniści podkreślają swoiste zalety tego typu przestrzeni, ponieważ „wydzielone strefy, dzielnice dla ubogich i fawele, wraz ze swoimi schroniskami, przytułkami, szpitalami, koszarami i więzieniami, rozwiązują nie tyle ten problem zamknięcia czy separacji, ile problem ruchu i krążenia, stanowią miejsca 
niepewności, są bowiem barierą oddzielającą dwie prędkości ruchu, pełnią funkcję hamulca (Virilio 2008: 18-19). Zanim przejdziemy do polemicznej dyskusji nad problemami tych domostw, spójrzmy na poszczególne studium przypadku oczyma turysty. Otóż, już na samym początku, w punkcie informacyjnym, znajdującym się przed wejściem do Santa Marty, odradzano turystom spacerów po dzielnicy, a zwłaszcza wchodzenia na wyżej położone obszary. W przekonaniu Anne Vigny:

osiedlanie się we wszystkich fawelach można uznać za ryzykowne. W rzeczywistości miasto pozbywało się swoich mieszkańców, którzy mieszkali na górze, bo chciano tam tworzyć punkty widokowe na Rio. Lekceważyli to, że ludzie mieszkali tam od urodzenia; jak w Santa Marta, którą spacyfikowano jako pierwszą. (Vigna 2013: 19)

Krocząc tropem nowoczesności należy zauważyć, iż przeobrażenia pacyfikacyjne sięgają 2008 roku. Przytoczmy jedną z wypowiedzi:

potrzebna była nowa długofalowa polityka, dzięki której państwo nadrobiłoby zapóźnienia w Rio z ostatnich dziesięcioleci. Pod koniec 2008 roku gubernator Cabral ogłosił nową strategię, tzw. pacyfikację, po portugalsku pacificação, częściej określaną jako UPP - od pierwszych liter nazwy zaangażowanych w nią jednostek policji (Unidade de Policia Pacificadora, czyli Jednostka Pacyfikacyjna Policji). (Glenny 2016: 224)

Policja, stale obecna w dzielnicy, przejęła kontrolę nad fawelą. Za jedno z podstawowych zadań tej akcji należy zaliczyć usunięcie gangów narkotykowych i zredukowanie przestępstw tak, aby wprowadzić program społecznej transformacji ukończony 22 grudnia 2008 roku. Początki pacyfikacji splatają się z nadejściem „wyjątkowej koniunktury" wraz z momentem, w którym

miasto wygrało organizację olimpiady i po raz pierwszy ówczesny prezydent Luiz Inácio Lula da Silva (z lewicowej Partii Pracowników) oraz gubernator stanu, Sérgio Cabral i burmistrz Rio, Eduardo Paes (obaj z centroprawicowej Partii Brazylijskiego Ruchu Demokratycznego, PMDB) zawarli przymierze polityczne. (Vigna 2013:19)

Warto przy tym zauważyć, że „sam Beltrame zawsze zaprzeczał, jakoby istniał związek między pacyfikacją a faktem, że Rio będzie gospodarzem dwóch wielkich imprez sportowych” (Glenny 2016: 226). Niemniej jednak, „głównym celem miało być »ucięcie głowy« gangom narkotykowym, które rządziły poszczególnymi terytoriami, poprzez aresztowanie lub eliminację ich głównych przywódców. Po takim najeździe na terenie całej faweli zaczęłyby działać nowe jednostki policji” (Glenny 2016: 226). Wspomnianej perspektywie towarzyszył rozwój szeregu inicjatyw mających na celu rewaloryzację biednych dzielnic i próbę „przemianowania ich wizerunku i samego nazewnictwa wiązanego z zerwaniem stygmatyzowania ich i postrzeganiem w kategoriach terytorium wykluczenia” (Vigna 2013:19). Charakteryzując przemiany terminologiczne tej specyficznej przestrzeni i, Misha Glenny podkreślał, iż „rzeczownik pospolity „fawela” się przyjął. Zaczęto go używać w miastach w całej Brazylii. Jednakże w Rio konkurowała z nią inna, bardziej prozaiczna nazwa, żeby w końcu wygrać tę rywalizację 
- o morro, czy wzgórze. W innych częściach kraju największe fawele znajdują się na obrzeżach miast - z dala od wzroku zamożnych mieszkańców zielonych dzielnic o standardach życia porównywalnych z odpowiednikami z Nowego Yorku czy Londynu. Dlatego tylko w Rio fawele są znane jako Wzgórze” (Glenny 2016: 46). Nietrudno zauważyć, iż stopniowo odchodzi się od używania słowa „fawela” na rzecz bardziej ogólnego morro - wzgórze, comunidade popular, wspólnota ludowa lub najprościej communidade (wspólnota). Santa Marta zyskała sobie opinię dzielnicy owładniętej przemocą w wyniku działalności gangu narkotykowego Commando Vermelho (Czerwony Rozkaz). Początki tego ruchu sięgają 1971 roku, kiedy to powstała Grupa Związkowa, „która wkrótce została przechrzczona na Czerwoną Falangę, zanim w końcu zdecydowała się na Czerwone Komando - często skracane do pierwszych liter portugalskiej nazwy CV" (Glenny 2016: 62).

Pacyfikacja wzgórza, eliminując handel narkotykami, zmierzała jednocześnie do zerwania z postrzeganiem ich w kategoriach mekki „illegalizmów”, drug trafficking i wojnami narkotykowymi. Wewnątrz niej każda z części faweli posiada własną nazwę i swoją historię.

Pacyfikacja każdej faweli angażowała setki, a czasem nawet tysiące policjantów, których trzeba było wycofać ze służby w innych punktach miasta. Po kilku miesiącach wstępna okupacja dobiegał końca. Na miejscu instalowała się jednostka pacyfikacyjna, złożona ze specjalnie do niej wyznaczonych funkcjonariuszy policji, którzy mieli zapewnić mieszkańcom, że od tej pory siły państwowe są w faweli obecne i stałe, a handlarze już nie wrócą (Glenny 2016: 260).

Społeczność stara się zmienić postrzeganie publiczne całej faweli poprzez większe otwarcie jej na przybyszów z zewnątrz. W trakcie pacyfikacji nastąpił proces przekształcenia budynków, uznanych za mekki działań kryminalnych, w miejsca użyteczności społecznej. Jednym z najbardziej wyrazistych przykładów takich miejsc jest budynek nazywany powszechnie „Bejrutem”, w którym ukrywali się handlarze narkotyków. Jednak w trakcie pacyfikacji został on przekształcony w salę sportową przeznaczoną do uprawiania boksu i judo.

Do najważniejszych efektów pacyfikacji należy zaliczyć działanie budzące niezadowolenie miejscowej ludności. Jednym z najbardziej kontrowersyjnych kroków, podjętych przez politykę miejską ówczesnego prefekta municypalnego Eduardo Paesa w 2009 roku, było skonstruowanie murów otaczających fawelę. Ich zadaniem było uniemożliwienie horyzontalnego rozrastania się począwszy od Santa Marty (Perlman 2010: 28). Ponadto, owa fawela została „oddzielona murem od zielonych terenów z prawej strony miasta. Jest również krytykowana arbitralność policji w podejściu mieszkańców” (Luci de Oliveira 2014: 148). Polemicznie patrząc na powyższe obostrzenia terytorialne należy pamiętać zalecenia Georga Simmla. Otóż, według niemieckiego uczonego, „każda gmina wykracza poza swoje bezpośrednie granice, toteż styka się ze wszystkimi innymi aktywnymi na tym samym totalnym obszarze i na tym obszarze żadna inna gmina nie jest jedyna, wokół węższego obszaru jej wyłączności roztacza się obszar szerszy, na którym jedyność jej już nie przysługuje. Ta lokalna forma życia grupowego może powtórzyć się również wewnątrz miasta” (Simmel 2008: 368-369). 
Oznacza to, iż obszar faweli współistnieje z rozległym otoczeniem przestrzennym leżącym u jej podnóży, dzięki czemu wydaje się, iż związek i bezproblemowy tranzyt powinien być zachowany. Jak piszą urbaniści „na gruncie współczesnych koncepcji przestrzeni nie da się obronić poglądu, iż zamiast otwarcia, ekspansji, wolności wiązanych z przestrzenią, miejsce określają bariery, skrępowanie, przymus” (Rewers 1996: 51). Za drugi problematyczny aspekt rozwoju wzgórza można uznać „wzrost kosztów utrzymania i widmo »białego wydalenia« (...) w procesie gentryfikacji tych przestrzeni, szczególnie w fawelach posiadających uprzywilejowaną lokalizację” (Luici de Oliveira 2014: 148). Polepszenie warunków życiowych nieodmiennie pociągnęło za sobą podwyższenie kosztów życia. Jedną z ważniejszych osi problemowych, wokół których toczy się dyskusja jest to, iż „nie ma konsensusu z mieszkańcami, jeśli idzie o zasady tworzenia polityki publicznej” (Luici de Oliveira 2014: 148). Stąd też wynika problem, że narzucone rozwiązania miejskie nie zawsze odpowiadają na zapotrzebowanie ludzi tam mieszkających. Otóż poszukując alternatyw w ramach programu pacyfikacji, postanowiono zorganizować kursy elektroniki i fryzjerstwa, mające poszerzyć możliwości rozwoju faweli o inne rodzaje aktywności i zarabiania pieniędzy. Miejscowa ludność w większości podziela przekonanie, iż te kursy w niewielkim stopniu mogą wydać się im użyteczne, co jednocześnie buduje napięcie pomiędzy odgórnie narzuconymi programami przez rząd a oporem mieszkańców. Szczególnym zainteresowaniem mieszkańców cieszy się nauka muzyki i tańca. Jednocześnie znajduje się w tej faweli czynnie działająca szkoła samby. O tym świadczą dźwięki samby rozbrzmiewające u jej podnóża. Jednym z najbardziej użytecznych elementów przebudowy faweli jest niewątpliwie usprawnienie połączenia jej podnóża z górną częścią wzgórza, poprzez budowę kolejki tramwajowej. Rozpoczyna ona swój bieg u podnóża wzgórza i wspina się pod kątem czterdziestu pięciu stopni do górnej jej części. Jednak w czasie prowadzonych obserwacji, w drugiej połowie lipca 2017 roku, pozostawała ona tymczasowo nieczynna. Droga prowadząca do kolejki charakteryzuje się bogactwem kolorów wyrażanych w urozmaiconych malunkach, wykonanych na ścianach w różnorodnej formie, nawiązujących niekiedy do samby i kultury ludowej Rio. W świetle niniejszych spostrzeżeń można zauważyć, iż wspomniany projekt odpowiadał na zapotrzebowanie społeczne, otwierając swoją przestrzeń mieszkalną na turystów i jednocześnie usprawniając komunikację, co wydatnie - przynajmniej w założeniu - miało się przyczynić do poprawienia związku między podnóżem wzgórza a jego górną częścią. Niemniej jednak autor tego tekstu nie mógł zweryfikować rzeczywistej wartości tego projektu, ponieważ projekt ten pozostawał w fazie rekonstrukcji.

\section{WOKÓŁ PROJEKTU OH MORRO}

W gronie najważniejszych działań zmierzających do renowacji wzgórza przeprowadzono grupę projektów artystycznych, do których należy zaliczyć oświetlenie wzgórza wielobarwną grą fasad domów, flankujących główny rynek u podnóża faweli. Oprócz tego można było zobaczyć lub sfotografować wielokolorowe fasady domów u podnóża faweli, z jej bogactwem kulturowym i możliwością zobaczenia pejzaży miejskich z punktów widokowych. Rozwój zainteresowań sztuką dizajnu miejskiego przyczynia 
się do dalszej niwelacji odrębności fasad budynków przez sprowadzenie ich do roli znaków. I te koncepcje znajdują wyraz w działalności ekspozycyjnej ostatnich lat, operującej tendencją do rozwoju komunikacji wizualnej. W związku z tym do rewitalizacji faweli zaproszono Jeroena Koolhaasa i Dre Urhahn w celu pokolorowania trzydziestu czterech fasad faweli na kolor zielony, niebieski, żółty, różowy i pomarańczowy w różnych zestawieniach, w ramach malarskiego projektu pt. Oh Morro rozpoczętego w 2010 roku (Carol O’Connor 2012: 32). Oznacza on dosłownie „O wzgórze”, na podkreślenie zaskakującego wrażenia objawiającego się oczom turystów. Dwuznaczne użycie tej nazwy wiąże się z tym, iż w języku portugalskim słowo la morro, podobnie jak a colina służyło jako synonim slumsów i faweli. Początek genezy tego projektu wiąże się z nazwiskami Koolhansa i Dre Urhansa, którzy od 2006 roku wprowadzili w życie ideę interwencji artystycznych promowanych przez wspólnoty w Brazylii. Owocem tych działań były między innymi dwa malowidła ścienne namalowane w Vila Cruzeiro w Rio de Janeiro. Za trzecią fazę projektu można uznać proces przemalowania fasad budynków u podnóża Santa Marty. Celem realizacji tego projektu, zatrudniono miejscową młodzież, żeby wzmocnić poczucie wspólnoty, umożliwić alternatywne formy zarobkowania i zapoczątkować nowe oblicze ubogich dzielnic. Każdy z budynków został pokryty trzema lub czterema kolorami malowanymi w pasma, celem zasygnalizowania zmiany wizerunku faweli. Wspomnijmy o tym, jak pisał Lévi-Strauss, iż „kolorowanie, obejmując nawet eksperymenty w dysonansie, podobnie jak jego ekwiwalent w muzyce było szokiem w tym czasie i przyniosło ogromną ekspansję artystycznej wrażliwości" (Lévi-Strauss 1997: 35). Aby wyróżnić zróżnicowanie kolorystyczne i etniczne Koolhas i De Urhahn próbowali wyrazić równowagę w kompozycji, odnajdując spokój i harmonię w symetrycznym kolorowaniu fasad, by nadać im oddźwięk widoczny z oddali. Otóż, jak powiadał Lévi-Strauss: „w malarstwie, wewnętrzne właściwości kolorów są podporządkowane stosunkom, które artysta ustanawia między nimi” (Lévi-Strauss 1997: 67). Gra kolorem wykreowana na fasadach konotowała otwartość na różnorodność i brazylijską żywiołowość. Chcąc w wyrazisty sposób zaświadczyć o rozwoju tej wspólnoty, Koolhas i De Urhan podjęli się odzwierciedlenia jej przekształconego oblicza w nowym świetle wielokolorowych przeobrażeń miejskich będących odbiciem jej różnorodności etnicznej. Projekt ten w szczególności odznaczał się tym, iż poddawał dotychczas istniejące obiekty budowlane renowacji, przywracał go szerzej opinii społecznej, angażując całą społeczność do zmiany wizerunku, by wyodrębnić detale dotąd niezwracające uwagi i przeobrazić je w widzialne elementy będące wschodzącą marką wernakularnej kultury carioca. Obfituje on w kilkadziesiąt ośrodków gastronomicznych, udostępniających turystom możliwości spożycia potraw lokalnych i zakup pamiątek w akompaniamencie lokalnej muzyki, przy dźwiękach samby. Zważywszy na szereg zależności ekonomiczno-społecznych można powiedzieć, iż „kreatywność odzyskującej prawo do miasta wielości polega w tym wypadku na niezwykle trudnym do osiągnięcia zachowaniu kulturowych zasobów miejsca” (Juskowiak 2013: 304).

\section{TARAS WIDOKOWY}

Obok betonowych budynków w większości mieści się tam kilkaset budynków wykona- 
nych z drewna, wzniesionych na jednym z najbardziej stromych wzgórz w Rio. Choć istnieją ścieżki między pierwszą a drugą częścią faweli, przejścia pomiędzy nimi zdają się naruszać sferę prywatną autochtonów. Przechodnie nieustannie natrafiają na grupy dzieci na wąskich schodach prowadzących na górę i na sklepy spożywcze, w których można zakupić artykuły gastronomiczne. Droga prowadzi do miejsca, w którym znajduje się pomnik Michaela Jacksona, wykonany w brązie ku pamięci muzyka, który nagrał w tym miejscu fragment teledysku They don't care about us w reżyserii Spike'a Lee w 1996 roku wydany na płycie History ${ }^{1}$. Stamtąd rozciąga się bowiem niesamowity widok na Rio.

Zdając sprawę z kontekstów kulturowych leżących u podstaw realizacji tego video-klipu, zauważmy, iż filmowanie jego pierwszej wersji zostało opóźnione o dwadzieścia dni. Owo przesunięcie czasowe wynikało z faktu, że prefekt Rio de Janeiro obawiał się, iż sfilmowanie dzielnicy Santa Marta może negatywnie wpłynąć na szanse Brazylii na organizację Igrzysk olimpijskich w 2004 roku. Publikacja promocyjnej wersji piosenki wzbudziła kontrowersje związane z rzekomym przemycaniem treści antysemickich przez Jacksona. W rezultacie ingerencji cenzury treść piosenki została szybko zmieniona w ostatecznej wersji ${ }^{2}$. W odpowiedzi na głosy krytyczne, Jackson odparł w wywiadzie, iż adresatem jego piosenki były ofiary uprzedzeń. Inaczej mówiąc, utwór ten z punktu widzenia „pierwszego świata” zwracał uwagę na problemy społeczne „trzeciego świata” ${ }^{3}$. Aby utrwalić wspomnienie po tym wydarzeniu, wzniesiono mimetyczny pomnik Jacksona naturalnej wielkości. Na tym tarasie znajduje się mozaika przedstawiająca podobiznę twarzy Jacksona w różnorodnych kolorach i konotująca ikonografię Stanów Zjednoczonych. Warto zauważyć, iż owo miejsce służy jako ważny punkt widokowy, skąd można obserwować panoramę zwróconą na centrum Rio De Janeiro. Stamtąd rozciąga się widok zwrócony na Ipanemę i Leblon, wzgórze Corcovado, na którym była położona statua Cristo Redendor. Na placu mieszczą się też punkty sprzedaży, gdzie można kupić pamiątki i artykuły gastronomiczne. W jednym z nich można zauważyć telewizor, na którym odtwarzany jest non-stop w pętli projekcyjnej utwór Michela Jacksona, jak również specjalnie przygotowane lokalne suweniry i wzornictwo reprezentujące lokalną ikonografię. Na szczególną uwagę zasługują koszulki z nadrukiem rysunku jedenastoletniego syna sprzedawczyni. Obraz ten odzwierciedla przekrój faweli od podnóża do samej góry, przechodzący poprzez wszystkie kondygnacje i widniejący w tle nad wzgórzem wizerunek Cristo Redendora. Rysunek ten stanowi główny element designu umieszczonego na koszulkach, haftach, torbach, butach. Istotnym punktem współkształtującym infrastrukturę tego placu, jest sklep gastronomiczny, gdzie można zaopatrzyć się w żywność i napoje w trakcie odpoczynku przy tarasie. Nawiązując do własnych doświadczeń, choć podczas obserwacji nikogo tam nie spotkałem, to w Internecie można odnaleźć zdjęcia ludzi robiących so-

\footnotetext{
${ }^{1}$ Dodajmy, iż Michael Jackson nagrał ten vide-klip częściowo wraz z zespołem Olodum w zabytkowej dzielnicy Perulinho, będącej wizytówką Salvadoru de Bahia i umieszczonej na liście zabytków w UNESCO.

2 Otóż słowa takie jak „jew me” zostały zmienione na „chew me” a „kike me” na „hike me”. Patrz: Jewish Response to Jackson, 1995.

${ }^{3}$ Choć nie należał do najczęściej puszczanych w stacjach radiowych, zdobył on w Europie popularność, plasując się w pierwszej dziesiątce list przebojów.
} 
bie zdjęcia przy pomniku Michaela Jacksona. $\mathrm{Z}$ tego miejsca można udać się w stronę boiska sportowego położonego na tej samej wysokości, przed którym bawią się dzieci na wąskich dróżkach. Zabudowania, wokół których można się poruszać, najczęściej wykonane są z betonu i nie przekraczają dwóch i pół metra wysokości, często utrzymane w stanie ledwie nadającym się do zamieszkania. Dodajmy, iż o niezadowoleniu społecznym świadczą liczne napisy na ścianach, głoszące hasło „gentryfikacja” w języku portugalskim. Biorąc pod uwagę wiele dróg interpretacji tego napisu, komunikat ten można postrzegać jako szczególny wyraz oporu miejscowej ludności wobec przymusowej restrukturyzacji przez władze miejskie, powiązany z procesem miejskich operacji „renowacji”, „przekwalifikowania” lub „rewaloryzacji”.

Tymczasem na szczycie wzgórza, w miejscu, w którym niegdyś mieściło się centrum opieki społecznej, władze miejskie wzniosły Komisariat Policji będący jednym z kluczowym elementów przeobrażeń pacyfikacyjnych. Aby uchronić wzgórze przed inkryminacją, powołano do działania w tej jednostce specjalnie wyszkolone jednostki policji policia pacificadora (policji utrzymującej pokój), stale obecnej w społeczności i usuwającej dealerów (Perlman 2010: 372). O napięciach w relacji między strażą miejską i miejskimi gangami świadczą widniejące dziury na ścianach od kul, będące pozostałością po konfrontacjach z dealerami.

Obok zaś Komisariatu, na samej górze, znajduje się wyjście z kolejki przeznaczonej dla turystów, aby stamtąd podziwiać wzgórza biednych dzielnic. Osobiście zastanawia mnie, dlaczego nie spotkałem żadnego turysty na tarasie z pomnikiem Jacksona, ani na samej górze, skąd można było obserwować wzniesienia. Nie trudno stwierdzić, iż tej przestrzeni mieszkalnej brakuje uważnego nadzoru władzy, a każdy ze zwiedzających wybiera się pod górę na własne ryzyko, nawet do miejsc widokowych, ponieważ w trakcie wędrówki można odnaleźć uzbrojonych miejscowych, pełniących rolę gatekeeperów. Strzegli oni domostw i porządku w punktach widokowych. Trudno dokładnie powiedzieć czy napotkana przeze mnie dwójka osób w cywilnym ubraniu była to straż obywatelska czy grupa gangsterów chcących wymusić opłatę za wejście do punktu, w którym Michael Jackson nagrywał swój utwór. Interwencja ze strony właściciela sklepu, od którego zakupiłem lokalny specjał sprawił jednak, że nie musiałem tłumaczyć się z obecności w tym miejscu po krótkiej informacyjnej rozmowie.

\section{W STRONĘ WYJŚCIA Z CIENIA INKRYMINACJI}

Biorąc pod uwagę przedstawione wyżej koncepcje merytoryczne, wyznaczające - zdaniem urbanistów - krytyczną analizę ubogich dzielnic należy podkreślić, z jednej strony, koncepcje odseparowania ich od innych części miasta, z drugiej zaś, procesy pacyfikacyjne mające na celu ich kreatywną restrukturyzację i zachęcenie do odwiedzania ich przez widzów. Można przypuszczać, iż miejsce wzgórza Santa Marta w przestrzeni urbanistyki Rio de Janeiro jest ambiwalentne. Santa Marta należy do jednej z najbardziej dwuznacznych wzgórz ze względu na podwójny charakter wiązany z nieufnością turystów, wywołaną kryminalną historią dzielnicy i chęcią jej ponownego odkrycia w nowej formie wizualnej. Powstaje problem czy dotychczasowa restrukturyzacja miejska zawiera „gotowe” odpowiedzi na postawione wyżej pytania. Inaczej mówiąc, czy 
dotychczasowe przeobrażenia miejskie mogą doprowadzić - w jej sensie literalnym - z uwagi na zadania postawione w procesach pacyfikacyjnych do przywrócenia ich miastu i otwarcie ich na turystykę. A jeśli nie, to w jakim kierunku powinien pójść rozwój tej polityki, by mogła sprostać temu zadaniu. Można zaryzykować stwierdzenie, iż polityka miejska prowadzona przez władze Rio de Janeiro w niewielkim stopniu jest w stanie przeciwstawić się dzisiejszej inkryminacji biednych dzielnic. Pomimo głosów krytycznych mieszkańców, związanych z odgórnie narzuconymi zmianami, uważa się jednak, że owa pacyfikacja „częściowo” (Luci de Oliveira 2014:181) poszerzyła podstawowe prawa obywatelskie mieszkańców do wolności, otwierając więcej możliwości na zarobkowanie w różnorodnej formie. Znakomita większość turystów trafia wyłącznie do przestrzeni konsumpcyjnej u podnóża faweli, bojąc się wkroczyć na wyższe piętra. Kluczowym aspektem wyróżniającym wzgórze Santa Marta od innych faweli w Rio jest, jak pisała Jeanne Perlman, to, iż posiada ona „długą historię porywającego przywództwa i mobilizacji społeczności, a także wspaniałe widoki miasta, które mogą przyciągać zagranicznych gości” (Perlman 2010: 328). Trudno jednak oczekiwać, że pewnego dnia nastąpi boom de gringos (Luci de Oliveira 2014: 30), mogący ogarnąć całe wzgórze. Zastanawiając się nad dalszymi krokami prowadzącymi w stronę restrukturyzacji wzgórza, należałoby dokonać w tej dzielnicy większej ilości inicjatyw, co mogłyby pozwolić na korzystanie z usług oferowanych turystom przez miejscową ludność. Nie ulega wątpliwości, iż projekt odnowy przestrzeni miejskiej za pośrednictwem wielobarwnego wzornictwa, jak również umożliwienie korzystania ze specyfiki kulinarnych specjałów, nie tylko dowartościowuje to miejsce, kojarzone z miejscami przemocy i handlu narkotykami. Ewidentnie służy także do przyciągnięcia większych rzeszy turystów zwabionych rytmami samby. Wraz z przekształceniem oblicza wzgórza Santa Marta można zwrócić uwagę na dążenie do zapewnienia bezpieczeństwa odwiedzających, poprzez powołanie do tego specjalnych służb i umożliwienia skorzystania z porad w punktach informacyjnych. Badacze przestrzeni miejskiej Rio wskazują częstokroć w swoich analizach, że próby reaktywacji i ponownego wykorzystania ekonomicznego potencjału tego miejsca powinny korespondować z dobrowolnym zaangażowaniem i przygotowaniem do tego miejscowej ludności. Próba restrukturyzacji istniejących miejsc nie powinna zagrażać jej spójności społecznej i skutkować wysiedleniem. Jednocześnie problematyczna wydaje się asymetria między dolnym odcinkiem wzgórza otwartym na obecności turystyki a górnym punktem widokowym wzgórza, dokąd dochodzi kolejka. Stąd też wynika dysonans pomiędzy wielokolorowymi fasadami u podnóża wzgórza a bezbarwnym szarym widokiem betonowych domów, skąd paradoksalnie roztacza się najbardziej okazały widok na Rio. Do najbardziej zasadnych rozwiązań na wyjście z kryzysu tej wspólnoty należy zaliczyć większe otwarcie na obcych spotykanych na górze samego wzgórza. Trudno oprzeć się wrażeniu, że obecność masowej turystyki staje się, jeśli nieodzownym, to chociażbym wartościowym elementem rozwoju wzgórza, bez której nie sposób myśleć o rzeczywistej zmianie infrastruktury tego miejsca. 


\section{BIBLIOGRAFIA}

Barker, Chris. 2005. Studia kulturowe. Teoria i praktyka. Kraków: Wydawnictwo Uniwersytetu Jagiellońskiego.

Carol O'Connor, Lindsey. 2012. Sites of Possibility: Political Subjectivity and Process of Self-Representation in Rio de Janeiro's Favelas. Art History Theses \& Dissertations, 100.

Glenny Misha, Nemezis 2016. O człowieku z faweli i bitwie o Rio. Wołowiec: Wydawnictwo Czarne.

Jewish Response to Jackson. 1995. New York Times, June 16. Pobrane z https://www.nytimes.com/1995/06/16/arts/jewish-response-to-jackson.html.

Juskowiak, Piotr. 2013. Spór o wspólnotę $w$ perspektywie badań nad miastem postindustrialnym. Maszynopis dysertacji doktorskiej, Instytut Kulturoznawstwa UAM.

Luici de Oliveira, Fabiana. 2014. Cidadania, justiça e pacificação em favelas cariocas. Rio de Janeiro: Editora FGV.

Lévi-Strauss, Claude. 1960. Smutek tropików. Warszawa: Państwowy Instytut Wydawniczy.

Lévi-Strauss, Claude. 1997. Look, listen, read. New York: Basic Books.

Perlman, Janice. 2010. Four decades of living on the edge in Rio de Janeiro. New York: Oxford University Press.

Rewers, Ewa. 1996. Język i przestrzeń w poststrukturalistycznej filozofii kultury. Poznań: Wydawnictwo Naukowe UAM.

Simmel, Georg. 2008. „Socjologia przestrzeni”. W: Pisma socjologiczne (ss. 365-385). Warszawa: Oficyna Naukowa.

Soja, Edward. 2000. Postmetropolis. Critical Studies of Cities and Regions. Oxford \& Malden: Blackwell Publishers.

Vigna, Anne. 2013. Rio - pacyfikacja czy podbój? Le monde diplomatique, 1/2013 s. 19. 


\section{Ambivalent image of the Santa Marta favela view against the back- drop of changes related to pacification}

ABSTRACT: The article seeks to create an approach that would challenge the description of transformations of Santa Marta favela in Rio de Janeiro, which presents the ambivalent image of this space born after its pacification and seen in the prism of Edward Soja's post-industrial analysis. In pursuing this, the author discusses the potential threats triggered by separation from the other parts of the city, gatekeeping, incrimination. Finally, the text shows how urban restructuration Santa Marta favela articulates new solutions, despite its criminal history, through raising the interest of visitors by colouring the facades of residential houses at the foot of the hill in the framework of the project Oh Morro by Jeroen Koolhaas and Dre Urhahn.

KEYWORDS: Rio de Janeiro, Santa Marta, hill, separation, pacification, viewing terrace, gentrification 
